\title{
István OLAJOs* \\ The opportunities and place of fishing and angling in our natural waters ${ }^{* *}$
}

\author{
Abstract
}

This article is about the issues of the fishing right, as a property value right, and its exercise. The article analyses the issues of our natural waters' fishing and angling utilisation, the registration of fisheries management waters related to the appear of the fisheries management right, furthermore the article makes a proposal to solve the arisen public and private problems.

Keywords: fishing law, fishing right, Hungarian fishing act, rural development

\section{Guideline and questions to be answered}

Due to the amendment of the Fishing Act in 2017, fishermen living from water and fishing companies were out from our natural waters, because the Act directly prefers the angling utilisation. By the way the most important question of this article is what the role of semi-natural angling utilisation will be to the aquatic life, the protection against water damage, the accessibility of our natural waters, the indestructibility of the waterfront habitats, the issues of the agricultural utilisation of waters.

The first result of the made set of measures is that the conflict between the fishermen and anglers was further expanded. The fishermen excluded from the natural waters are increasingly forced to turn to artificial lakes and quarry ponds, which owners may be such owners, who exercise the state ownership and furthermore such natural persons, whose are interested in theoutside fishing economic utilisation of their waters. It is an important questions whether the sacrement of the ownership and the compliance of all three part licenses predominate in case of fishing waters. How the utilisation opportunities of fishing rights differ from the opportunity of the hunting area utilisation in the aspect of the owner of waters? Are there any measures in the modified Fishing Act which protect the owners of waters?

The other questions are how the fishing companies ensures the living of the fishermen excluded from the natural waters, whether the hungarian fisheries management plan has programs to the recruitment of work capacity released in the area and the evolving more intense fisheries management activity is capable to ensure job opportunity for fishermen in the fishing processing industry. Can the variety trials

István Olajos: The opportunities and place of fishing and angling in our natural waters - A horgászat és halászat lehetőségei és helye természetes vizeinkben. Journal of Agricultural and Environmental Law ISSN 1788-6171, 2019 Vol. XIV No. 27 pp. 131-159 doi: 10.21029/JAEL.2019.27.131

* dr. jur., PhD, associate professor, University of Miskolc, Faculty of Law, Department of Agricultural and Labour Law, e-mail: civoliga@uni-miskolc.hu

** The study has been prepared in the framework, of the programmes of the Hungarian Ministry of Justice aiming to increase the quality of training lanyers. 
activities of the fishing cooperatives can be extended, if it can not access to the reproducible entities of indigenous fish species arised from our natural waters.

\section{Fishing right, as the basis of acquisition on fishes}

Fishing appeared as a smaller royal sovereign right in the feudal law in Hungary. The smaller royal sovereign, as a granted entitlement, meant that the royal donation letter mentioned fishing right on the natural waters as the natural part of donation property together with the property. ${ }^{1}$

Kálmán Könyves have sought to change the legal nature of the aforementioned part in his no. 1 Legal Code, in which he confirmed the greater royal sovereign nature of fishing right, that is he provided if the fishing is not for the daily livelihood, for example the sustainment of the religious orders, it must be returned to the owner for royal usage. ${ }^{2}$

However, the mode of the right exercise was different from the legal code of the king in the later centuries. This fact was confirmed by three relevant provisions of Tripartitum made by István Werböczy. Firstly in case of the determining of the royal law and the law of possession, it designates the fishing ponds around the settlement as the accessory of the settlement. ${ }^{3}$ Secondly, he determined in the chapter on the lands flooded by rivers, that the person, who exercises his fishing right in the changed river bed, can follow the river bed during the exercise of his fishing right. ${ }^{4}$ The third mention is, that in case of the custodian's estimation of the asset of a child under custody, it must be estimated the ten times annual income from fishery on larger rivers and lakes, but if he can not account for this income, it must be estimated 50 gira. The value of 50 gira was the half value of a good stone castle. ${ }^{5}$

The fishing right, as the the basis of acquisition on fishes, could not be missed from the analysis of private law codification. In case of the evaluation of written resources of the right in rem, as the first resource of Barnabás Lenkovics's comprehensive analysis ${ }^{6}$ issued in 2003, the person, who catches the derelict fish, acquires the possession of the fish for the owner of the water. He mentioned the acquisition mode as one form of the derelict things in the part on the Austrian General Civil Code. ${ }^{7 n}$ the issue of Károly Szladits on Private Law, Bálint Kolozsváry, who wrote one part os the issue on the right in rem, evaluates as one case of the original acquisition generated by subjective private law, but still in the frame of the acquisition

\footnotetext{
1 Viktor Bérczes has an opposite opinion, who considers the fishing right as a greater royal sovereign right, as a ius regalium. Bérczes 2017, 75-76.

2 Veres 2001, 27.

3 Tripartitum Title 24 Section 7.

4 Tripartitum Title 87 Section 2.

5 Tripartitum Title 133 Section 41.

${ }^{6}$ Lenkovics 2003, 16.

${ }^{7}$ Austrian General Civil Code Section 381-387.
} 
of derelict things, if somebody acquires a possession on the fish caught during the exercise of the fishing right. ${ }^{8}$

By the entry into force of the Hungarian Civil Code, the attaching of the fishing right to the ownership of water. Lenkovics summarizes the serious dogmatic change as the following: „The original text of the Civil Code mentions the acquisition of ownership of game and fish separately from the acquisition of abandoned property as a separate acquisition mode. The rating of the game and fish as the subject of state ownership from the abandoned property and the separation of the hunting and fishing right, as acquisition rights, from the land ownership justified the aforementioned solution so far.Today, in general, the specially protection wildlife, living things and particularly natural assets justify this same solution, so the solution shall be to maintainedin the new act without any changes.It shall be determined in a separate act particularly on the ownership of game and fish, and the hunting and fishing rights, but it shall be referred to the aforementioned ownership and the rights in the Civil Code in order to underline the codes nature."

In his article, Lenkovics feels anachronistic the criterion of the interpretation of the Fishing Act in force at the time, accorting to which the entitled person, unless this act rules otherwise, acquires the ownership of the fish and other useful aquatic animal by lawfully catch. The ownership of the fish (or other useful aquatic animal) is the entitled person, if the fishing water are in the ownership of the entitled person. The dead fish (or other useful aquatic animal) will be owned by the owner of the fishing water, where it was found. ${ }^{10}$,This rule would be acceptable as a same exception to the artificial fish ponds and fish farms as the warrens and wildlife parks in case of game, but it is unnecessary and outdated.More and more plant and animal species, which creat the natural environment and within it the natural flora and fauna, become in the framework of the exclusive subjects of the state ownership, moreover in the framework of the subjects, which are not owned by human control, not possessed by anybody and specially protected living goods. Now fishing right is also an exemption from this trend prevailing general rule."11

The author would certainly be delighted such provision of the Fisheries Management Act, which considers the live fish as the subject of state property like in case of game, ${ }^{12}$ on which only the entitled person of the fisheries management right or the person authorised by him may acquire an ownership, who can personally exercise the acquisition right arising from the fisheries management right. However, according to the new act, the user of the right has obligation to the reduction of the invasive fish species and the sustainability of the proper ecosystem of native fish species. So the registration of the fish species protected by piece and size restrictions to the logbook together with the catch became a more important obligation then all previous

${ }^{8}$ Lenkovics 2003, 17-18.

${ }^{9}$ Lenkovics 2003, 19.

10 Act XLI of 1997 Section 8.

${ }^{11}$ Lenkovics 2003, 22-23.

12 Act CII of 2013 Section 6 (1). 
provision. As an administrative obligation, the registration became one of the essential condition of the acquisition of anglers. ${ }^{13}$

The fishing right and angling right, which were used synonyms by jurisprudence for a long time, was replaced by the expression of fisheries management right. The word also refers to the tendency that the farmer is not the fisherman or angler, who catches the fish, but also the economic body or the association of anglers, who lease the fisheries management right. The economic body or the association of anglersobtain income from the leased right by sales of territorial licenses for fishermen and anglers. However, they may not freely dispose of their income nor after the payment of lease fee. They have to solve from this income the replacement of the caught, native fish to their leased waters and the issues related to the fisheries control. ${ }^{14}$

The classic legal insitute determined as the prime sample of rights exercised by others, was given a new meaning as the part right of the ownership in the interpretation of fisheries management act. It became such a legal institute exploited by the Hungarian state owns the live fish and our most important waters and local governments own our ponds in not direct contact with other waters, where the leaseholder, besides his lease fee payment private obligation and other burdens arising from several public obligations, has to recruit a lot of fishermen and anglers in order to be profitable. If the owner creates the fishing waters as the scene of his economy creates on his own land, he is entitled to the fisheries management right. I would like to present the restrictions of the fisheries management right and the area of the fisheries management in details in the next chapters.

\section{The content of the fishing and angling rights and the restrictions of their exercise}

The first domestic act on fishing considers the fishing right as the inseparable part right of ownership and this fishing right are considered to the owner of the river or lake bed. ${ }^{15}$ Later, because of the alleged ambiguity of the registry of the water properties. 20 years of undisturbed possession of fishing right led to effective exercise of the fishing right by the owner guaranteed by the state. Fishing right exercise by this way become designated by a placard. ${ }^{16}$

The owner of the waterfront property was required to tolerate the exercise of fishing right, however the entitled person of the fishing right was liable full compensation for the damages caused by him during his exercise of the right in the waterfront property.

In the real socialist period, according to the primacy of the state ownership, the owner of fishing right was the state, except for ponds and rice fields built by the cooperatives, where the builders exercised the fishing right on the waters built by them.

\footnotetext{
13 Act CII of 2013 Section 6 (2)-(3).

14 Act CII of 2013 Section 12-18.

15 Act XIX of 1888 Section 3.

${ }^{16}$ Act XIX of 1888 Section 12.
} 
The operators of the personal waters also had this right. The exercise of the right was similar like at the end of the nineteenth century. The owner required to tolerate the entrance and the placing of fishing tools, howeverhis exercise of the right could not prevent the management of the land user. ${ }^{17}$

Besides the fishing right, the separated angling right was appeared in the Act of 1997 on Fishingm which over the difference of the two methods of fish catching and over the exercise of right required to an intensive, professional, and serious vocational exam or the qualification of fisheries management engineer, caused serious state income for agricultural organisations, who were authorised to exercise the fishing right regarding the area and won the right for the same period like a five-year plan, or for the possible social organisations.By contrast, angling can be considered as a hobby activity with a fishing rod and hook, furthermore asmall fish cathing net with a diameter of one meter, as one method of fish catching, for exercise, the anglers, who has reached the age of 14 and is entitled to exercise the angling right, has to take an exam before a committee on the identification of fish, the prohibition periods, the various angling methods, the behavior at the waterfront and the humane storage of the caught fish.In this case, this exam giving mainly theoretical knowledgewas organised and operated by the fishing authority and the body authorized to exercise the angling right.The Fishing Act, bearing in mind the fisheries management and fish protection, has imposed a number of restrictions related to the exercise of the fishing and angling rights.

The operator of the aquatic facility is obliged to notify the entitled person on the commencement of the water draining and filling activities and other activities, which restrict the exercise of fishing right and the expected duration, except in cases of emergency situations, at least eight days prior. For the contruction of a facility (modification, renovation, elimination, etc.) which restricts the natural movement of fish, the administrative approval of the fishing authority, the water authority and in case of natural or protected antural area is necessary.In order to ensure the spawning migration of high-value natural water fish stocks, the fishing authority obliges the operator of the river dam to set up and operate a fish ladder.In the spawning period of fishes, the operator of water facility is obliged to take into consideration of the environmental and ecological aspects during the water level control.18

In case of fish mortality in a fishing area, the owner and user (operator of the water facility) of the water, the user and owner of the waterfront property and the entitled person are obliged to allow and tolerate the water sample and the necessary examination and test for the animal health authority. ${ }^{19}$

It is forbidden to use such fishing accessories or fishing method for angling, which damage the fish stocks and its habitat. It is forbidden to use (a) poisonous or narcotic substances (b) explosive (c) sharp tool (d) harpoon or other diving accessories, which is suitable for fishing (e) raking method (f) looping fishing method for angling.

${ }_{17}^{17}$ Statutory Rule 30 of 1977 and Veres 2001, 28-29.

18 XLI of 1997 Section 16.

${ }^{19}$ XLI of 1997 Section 17. 
It is forbidden to use such a fishing equipment or device and fishing method, which, in case of avarage water level, continuously blocks more than one half of the river, backwater, tributary bed in the transverse direction. ${ }^{20}$

In order to the renewal of fish stocks and habitat, the entitled person is obliged to farm in the water besides the annual restocking of the typical species of the habitat in such a way that the fish stocks with a suitable age and density for the habitat is permanently maintained. ${ }^{21}$

The entitled person is obliged to guard the fish stocks and its habitat of the fisheries water exploited on the basis of fiheries management plan or ensure the guarding by a fishery guardian. A fishery guardian is also usable in other waters and fish ponds. A fishery guardian can be employed by more entitled person collectively. A field watchmen established by a special act is also assigned to do the issues of fishery guardian. ${ }^{22}$

Unless this act rules otherwise, it is forbidden to catch (collect) fish under nature protection. ${ }^{23}$

In the welfare area, in the period of the year determined by an administrative decision and during the prohibition, it is forbidden to do fishing, angling, hunting, boating, bathing, water sports and other activities, which interfere the reproduction or development of fish. ${ }^{24}$

The new Act of 2013 on Fisheries Management completes the aforementioned provisions with the following restrictions:

The structure of the Act was changed and in the aspect of the whole act, the animal protection became stronger. After the introductory provisions, the act regulates the protection of the fisheries management waters and fish stocks in two chapters. In order to the protection of fisheries management waters, the entitled person to fisheries management is obliged to protect the fish stocks, life community of water and the habitat of fish, promote the natural nutrition and reproduction of fish, furthermore perform the rescue of indigenous fish species in case of flooding or drying of the water. $^{25}$

Furthermore, the thinning of overpopulated vertebrate species, which destructs the fish stocks, the fishing and selective thinning of non-indigenous, invasivefish species, the limitation of nutrition and water transport, and the return of the uncovered juvenile fish stocks to the water are important habitat protection obligations. ${ }^{26}$

The specifically new fish protection measures are the following:the fish stocking of caughtindigenous fish species; the general prohibiton of fish stocking of caught non-indigenous, invasive fish species to natural waters; the strengthening of fishing welfare time, the size and number restriction on the basis of the application of

20 XLI of 1997 Section 23 (1)-(3).

${ }^{21}$ XLI of 1997 Section 25 (1).

22 XLI of 1997 Section 34 (1).

${ }^{23}$ XLI of 1997 Section 38 (1).

${ }^{24}$ XLI of 1997 Section $42(2)$.

25 Act CII of 2013 Section 8.

${ }^{26}$ Act CII of 2013 Section 8-12. 
the fish farmers or its' reduction in order to fishing and fishing tourism; and furthermore the determination of the general and fish under restrictions.

In case of mass deaths of fish, the entitled organisations to fisheries and water management, the owner of waterfront properties, the owner and user of water bed and the owner of water facilities are obliged to cooperate with each other.

After the identification and elimination of the results mof surface water pollution, the fish stocking of dead indigenous fish species is the obligation of the entitled person to fisheries management. In the spawning period, the owner of the water facilities are obliged to maintain the appropriate water level besides the establishment of a fish ladder. ${ }^{27}$

The nature of the fishing and angling right was changed. The horizontal role of these rights was disappeared, the angling-nature utilisation of our natural waters became the preferred right exercise form.

The reasons for this were stated by the legislator in its less intense, verifiable, and greater economic benefits. The new act only allows the fishing utilisation in the natural waters, if there is no candidate for angling-nature utilisation to the same natural water. ${ }^{28}$ I will present the opposite between the anglers and the fishermen, which was strenghtened by the entry into force of the act, in the fifth chapter.

\section{Our fisheries management areas}

The water suitable for fisheries management can be natural water and fisheries management water established by removing from agricultural and forestry utilization, which the owner registers in the registry of fisheries management areas and entitled to fisheries management.

This registration is preceded by the decision of the fishing authority on the qualification of the area as a fisheries management area.

The registration contains, besides the data of natural or legal person applicant, the land register reference number of the area, the zone of agricultural land, the ownership ratio and nem of the owner, the Hungarian water code, the EU water code, the area of the registered water, and the diameter in case of natural waters.

The utilisation mode of the fisheries management right is also indicated. The establisher of this kind of water can get automatically the fisheries management right after the submission of the five-years fisheries management plan.

If he is the owner of the full established water, the fisheries management right is entitled for him, so the right is forbidden to lease out for others. However, if the water is in co-ownership in undivided shares, the co-owners have only pre-lease right regarding the utilisation of fishing right. The utilisation rules of these areas will be analysed related to the changes of nature of fishing right. The statements about the fisheries management areas can be summarized as he following.

The basic unit of fisheries management is the natural or artificial water, which has biological communities specific to the subject of fisheries management as useful

\footnotetext{
27 Act CII of 2013 Section 12-16.

${ }^{28}$ Act CII of 2013 Section 5-6.
} 
water animals. From among our natural waters, the owner of waters determined in water management act is the Hungarian state, the owners of the ponds situated in the area of local governments are the local governments. On the areas under the scope of act on land and forestry management, an artificial fisheries management water can be established by removing from agricultural and forestry utilization, which becomes a fisheries management area by an administrative decision. Until the establisher owner would like to practise the water management activity on it, he is entitled to the fisheries management right, which he can practise on the basis of the plan under the supervision of fishing authority.

If the establisher would not like to practise fisheries management on the water in the future, the Hungarian state can utilise the fisheries management right of the area by leasing out, on which the owner has a pre-lease right and the opportunity to lease out this area. This opportunity is possible for the land owning community, who has share ownership on the removed area.

If nobody would like to exercise the fisheries management right, as similar to the natural water, the fishing authority at the name of the Hungarian state offers the water code area to the aim of angling utilisation, or fishing utilisation in case of the lack of interest. The person who obtained the fisheries management right, in case of angling utilisation, has the right to authorise its own members to practise angling activity by sale of annual and daily regional tickets and to obtain the ownership of the caught amount of fish by catching. ${ }^{29}$

\section{Fishing utilisation versus angling management. Are these interests coordinated with each other?}

The elimination of fishing on natural waters has brought many critics. Before the straightening of rivers, the significant part of the country's population lived from this ancient activity, and as our historical resources indicate, the fisheries, which were attached to a river or a pond, were one of the most important source of income of the gentry lived from land ownership.

The amount of water, which is arrived to our country by rivers, and the gradual water scarcity, which is arisen by the climate change, may make more and more significant that the water arrived to the area of our country in spring remains a longer period in the area of the country and makes possible that the country be able to the recharge of water in the rainless summer season. For this purpose, the capes, which make the special location of the Great Hungarian Plain possible, and the cape farming were established. In case of flood, the water of the river seeped through on the brakes, which is on the relatively protected high waterfront of the river, and flooded relatively large areas, flooding flatter areas. At the time of flowing, the water flooding the areas, were mostly seeped back into the riverbed, but remaining in the lower parts maked backwaters, mortlakes, and connective canal systems. By planting water tolerant fruit trees on the temporary flooded areas, it could be continuously ensured that the

\footnotetext{
${ }^{29}$ See Szilágyi 2017, 160-167. on the first analysis of the Act in respect of the change and taking into account the view of special utilisation modes.
} 
sediment of flood refills not the main branch of the river. After the flood, the extensive livestock farming and the utilisation of the sediment as an agricultural raw material became possible on the floodplain. However, for this mode of farming, the knowledge of the nature of the river was necessary and people living next to the river had to receive income from other modes. On the capes, typical fishing methods have been developed which have made possible that they could catch the largest fishes by the flooding water and the retreating water, while the juvenile fishes have enriched the wildlife of the river. ${ }^{30}$

The straightening of river made several areas suitable for intensive agricultural cultivation, but the rivers restricted between dams led to the decrease of traditional stages of fishing and the salination of the well-cultivated areas of the Great Hungarian Plain, furthermore the water scarcity led to the appearance of unknown animal diseases. But Hungary considered as the pantry of the Monarchy handled the emerging difficulties in the most cases. The compromise accompanying with the termination of feudal conditions could not give enough land for close to a million people, so the emigration, the activity arising from the situation, when a couple had only one child, the unfavourable economic environment between the two world wars increasingly made their impact. ${ }^{31}$ The water scarcity became more and more general, so for the availability of irrigation of the Great Hungarian Plain, the West Main Channel and the East Main Channel were built in 1930's, and after that the hydroelectric power stations in Tiszalök and Kisköre and Lake Tisza were also built for for regulating water level. Our waternature issues are more urgent, the dams of pur rivers are getting higher, and our rivers restricted between dams are not able to ensure sufficient spawning area for the indigenous fish stocks.

Related to the situation between fishing and angling, the anglers, who had better lobby activity, won against the fishermen. Fishermen, whose number was no more than 150 families in the last period, ${ }^{32}$ in the most cases their fishing activity was their part-time job, they fished only besides their full-time job and most time of the official fishing, they worked in fishing companies, so their livelihood were not in danger. ${ }^{33}$ The greater part of the professional fishermen lived their profession as an additional activity, but they considered the restriction of their activity, that their fishing enterprise, which ensured the continuous supplementary income, was ceased. A much bigger problem is, that people can not buy fresh, river fish neither in the bigger markets, furthermore the restaurants specialized to river fish next to river Tisza have to buy the most important raw material necessary for continuing these restaurants' activity from other resources, mainly from abroad. ${ }^{34}$ Fishermen, who have lost their activity, found the representative, who interpellated in case of their compensation. The National Assembly of Hungary explained their ministerial answer decided by an unanimous decision with environmental arguments, overfishing, and better catch options of the

${ }^{30}$ Nagy 2017.

31 Olajos 2010, 153-159.

32 Falusi 2016.

${ }^{33}$ Fazekas 2016.

${ }^{34}$ Falusi 2016. 
anglers. While their specific livelihoods are not in danger, the carry-out fishing equipment can be sold to the intensive fishing companies. According to the ministerial answer, the fishermen's expertise can be useful for the fish conservation and selective fishing of the natural waters. From an ecotourism point of view, the fishermen can play a role in the organization and implementation of tradition preservation exhibition and sight fishing, which of fishing opportunity's legal context is currently under development, furthermore the in the field of exploratory fisheries and vocational training. From a fishing tourism point of view, the fishing management function may get a major role in the future, and after a guide or tourism training and language education several people may be excellent to comply with the filling of this position. ${ }^{35}$

To go back to the ministerial answer, on the area of the saved coasts, by the establishment of well-built cape farming restricted between the frames of ecological farming, the fishing established on the capes, the grazing, the fruit plantations established on the beneficial effect of fresh sludge, water tourism travelled around well with kayak and the angling are compatible well with each other. On this kind of plantation, a fisherman, who work continouosly, and an angling tourist, who prastices his/her hobby and meets the sights of the area, may be compatible well with each other. The angling tourists may be accompanied to the appropriate places by applied fishermen.

The Szövetség az Élő Tiszáért Association proposed and presented program similar to the aforementioned proposal, which association operates in order to the fishing, which can be integrated to the the rural development, and water management, and issue its opinion about all theme-related legislation drafts. It is worth presenting some connecting points form the aforementioned opinion, because these may reflect the interests of anglers and environmentalists.

\section{1. ad1. 'Not only the ground, but also the water belongs to local people!'}

Wherever possible, local people and local organisations (local governments, civil society organisations, national park directorates) enjoy benefits related to the applying for waters. Applying for special waters be separately. For this, however, it is very important, that the special waters, backwaters and channels be disconnected from the big sections of rivers and waters, and similar to hunting companies, the fishing right be the hands of the local people. Do not lease a water by a foreigner. In case of the utilisation of water, the local people, the local organisations enjoy benefit, but if they can not work together (for example bigger water sections) or do not use their opportunities, someone else gets the possibility of lease. The goal is the fair management in both cases. The viable size of major section is 3000-20000 hectares (otherwise, the area is too small) and it is important, that 3 or 4 local governments can apply for this together.

In the aspect of angling utilisation, the prices of the regional tickets needs to be attractive for the anglers. It is important, that the abuses experienced so far do not remain without consequences, so the community and the 'fish judge' also be a

\footnotetext{
${ }^{35}$ Fazekas 2016.
} 
possibility that they summarize the experiences of the previous lease periods before the invitation to tender on lease rights. For this purpose, the statement of the members of the community concerned may be used. They can give important information to the invitation to new tenders. A honorary member of the local community would be appointed as a 'fish judge', who would execute the consultation before the litigation. The record of the people, who breached the rules of fishing, may be known by not only the fishing authority, but also the fishing and angling community. ${ }^{36}$

If the local governments or subregions apply for it, the water management would be achieved in local level, the water would be owned by a local person. The local people would pay attention to the order, the development of the habitats, the growth of fish stock, the wanton exploitation and the reduce of poaching. The number of employees employed in fishing would be increased, whose would have a serious role as an angler attendant in angling tourism. The obligation of the lessee would be to employ minimum one fisherman in every river settlement. The natural condition of the lease right must be an adequate fiheries management plan. For this purpose the local governments can work together with fishing farms and apply for the education of fishing skilled workers and the development of habitats. The water should be an owner, who knows the daily situation and the daily tasks. The utilisation of the special waters should be introduced as an experimental fisheries management method and should be applied for it in every 5 years. The introduction of the new lease system would also imply procedural changes, firstly, lease tenders on special water would be issued and if the tender is unsuccessfull, the lessee, who leases the water section, gets it with the obligation of spawn rescue. ${ }^{37}$

\section{2. ad 2. The textual characterization of fisheries management year}

Besides the catch logbook, because of the necessity of impact assesments and the analysises, a riport on the relevant year to be introduced for all people entitled for fishing and angling. For exploratory fishing, the consent of the entitled person for fishing not to be necessary, instead of it a mandatory declaration be necessary.

This proposal for changes enacted in research and nature conservation purposes reflects the interests of the environmentalist and the researchers and it would do the almost over- bureaucratized angling more complicated. In case of fishing card, state and regional ticket, size and piece restricted fishes, only a small number of anglers would accept voluntarily to prepare a riport on the relevant year besides the catch logbook completed at the same time of the catch and summarized at the end of the year. ${ }^{38}$

\footnotetext{
${ }^{36}$ I consider the local rulemaking in the original proposal and appropriate jurisdiction with a completely lay participation difficult to carry out.

37 Demény, Felső \& Cselószki 2016

${ }^{38}$ Demény, Felső \& Cselószki 2016
} 
5.3. ad 3. In case of the determination of the interested and competent administrative bodies, the interests of fisheries management be the primary

The goals of the water management and nature conservation, the nature value protection and the interests of fishing be coordinated. In case of the planning of water facilities and the water management, the interests of the fishing, the fish stocks, the natural ecosystem and the environment be taken into consideration better. Between the organisation, consultation obligation be with equal rights.

In order to the genetic protection of domestic and local varieties fishes, the control of cormorant stocks is necessary with the cooperation of the national park experts. It is important that the fish destructive animals (for example mammals and birds) be effectively regulate in the lake farms or be adequate compensation for the mitigation of crop failure. Currently, there is also a possibility to the thinning of cormorant. But the fishing companies do not really use it. Related to the elimination of nesting sites and the wandering stocks, it is necessary to deal with the possible solutions.

The nature conservation or even the economic-purpose breeding of the protected and endangered fishes should be allowed, and the support, the more increased regulation and repression of non-native species are necessary. Under different conditions, but the breeding of protected and endangered fish species be possible in Europe. Now it is possible, but only for nature conservation purpose, furhermore in case of sturgeron species, there are special provisions. The research of the existence of nature conservation reason is required additional resource. This takes back to the lack of fish stocks' data and statistics.

In return for support, the fish farmer would be obliged to take place one part of fish stocks $(60 \%)$ to the natural waters.

If in the spawning areas or fish waters established by the community protected fish species multiply, which were not found there earlier (for example because of the fact that the area was an arable land earlier), the protected fish species be fished in these water areas in $40 \%$ by the community and be marketable besides an adequate data transmission and monitoring activity. In case of protected species, the main goal of the fishing would be marked as the promotion of the reproduction of fish stocks to natural waters.

The reproduction and fishing of protected species need to be performed as a non-profit organisation, as the part of university cooperation or gene preservation activity.

The repression of invasive species need to be predominated better by the more intensive checking of plantations. In the fisheries management plans, the development of habitat and spawning areas need to be more focused against the reproduction of fish stocking. ${ }^{39}$

${ }^{39}$ Demény, Felső \& Cselószki 2016. 


\section{4. ad 4. The conditions of the establisment of fish pond and angling water need to be more simplified}

The conditions of the establishment of a fish lake or other periodic fishing water be simplier. All forms of water management need to be got support and the prices of water charge need to be reduced. If a community legally establishes a spawning area or fish lake by a cape or a retention of inland water, the owner of the fishing right be the community.

The lessee of the fishing right not to forbid the sale of the fish caught by the fishermen and the anglers as a small farmer or in the frame of village guest table service. The owner of the fishing right may only require a permission not covered by law for the caught fish. He not to forbid for an angler has an exam, an angling licence and a permission to the sale of caught fish as a small farmer or in the frame of village guest table service in the angling card or in other places.

Today the Fishing Act does not forbid the commercial exploitation (the sale of caught fish as a small farmer or in the frame of village guest table service) of the legally caught fish, moreover the governmental intention is the promotion of the appearence of the local products on markets. In case of live fish, the Ministry of Agricultural and Rural Development Decree no. 52/2010 on the conditions of production and sale of food by small farmers direcly allows or would allow the sale of caught fish as in the frame of village guest table service in the place of the farm nationwide up to the annual amount $6000 \mathrm{~kg}$. Nevertheless the thematic and gastronomic tourism route cannot be evolved and strengthened in view of national image, because the entitled people for fishing living their right that they can make a stronger and stricter regulation in their waters by the permission fishing supervisory committee, requiring this permission, they write down in the angling licence that any commercial exploitation is forbidden.

If a community ${ }^{40}$ or a natural person legally establish a spawning area or fish lake by a cape or a retention of inland water, the owner of the fishing right be the community or the natural person. The establishment of fish lake and other periodical fishing water (for example spawning area) be easier. The water management (irrigation, fish and rice production, fish lake management, establishment of spawning areas, inland water management) be coordinated and enjoys support. An effective inland water management can be established by the cooperation of farmers, water facilities and fishing companies (in inland water areas, it is possible with the establishment of lakes connected to the channel system and building raised agricultural roads from the extracted materials). ${ }^{41}$

\section{Summary of the results of the research}

The fishing right, which was qualified as the inseparable part-right of the waters' ownership for a long time, but it makes the owner entitled for the fisheries management or the sublessee the subject of the exercise of right from 2013.

\footnotetext{
${ }^{40}$ See on the scientific basis Kajner et al. 2005, 116-140.

${ }^{41}$ Demény, Felső \& Cselószki 2016.
} 
The acquisation on fish of the practical fishermen or angler is one form of the exercise of right by the entitled person. The acquisation on fish of the practical fishermen or angler has several public law obstacles, so with the compliance of the omission of these obstacles, the entitled person for fisheries management get the ownership on fish. The nature and role of the fish farmer's nature conservation fish farmer was increased. The fisheries management right of the establisher of a new fishing water is provided only for the first 15 years of fisheries management cycle. The artificial contradiction between fishermen and anglers can be solved through a more thoughtful fishing policy. Related to the exercise of fishing rights, the role of local communities should be increased. The utilisation right of special waters should be left to the local governments. The issues of water and fisheries management authorities and the nature conservation authority should be harmonised. In case of the establishment of fishing areas, the fisheries management right of the owner should not be diminished.

The research may be further developed answering the following public nature questions:

The angling regulation has been changed at the same time with the increase of the angling utilisation. The number of fish species affected by prohibition period has increased and size limits have also increased. In addition, in favour of the prevention of corruption, the rules of the fishing controls have been changed, the imposed penalties have increased, and besides the sui generis administrative penalties based on Act on Offences, criminal penalties have been introduced for the failure to comply with the rules of angling. Besides the exposition of the aforementioned measures' reasons, with the background of 3 years practise, I would like to determine the balance of the set of measures. 


\section{Bibliography}

1. Act XIX of 1888 on Fishing

2. Act XLI of 1997 on Fishing and Angling

3. Act CII of 2013 on Fisheries Management and Fish Protection

4. Rule 30 of 1977 on Fishing

5. Tripartitum (1514) Tripartitum of the Aristocratic Hungary's Common Law

6. Austrian General Civil Code

7. Bérczes V (2017) Az orvhalászat szabályozási módszerei és dogmatikai kérdései, Miskolci Jogi Szemle (1), pp. 74-86.

8. Demény F, Felső B \& Cselószki T (2016) Nem csak a föld, a víz is legyen a helyben lakóké, Javaslatok és indoklásuk, a magyarországi halászati törvény, és egyéb kapcsolódó jogszabályok módosítására, 1-6, http://www.elotisza.hu/uploads/dokumentumtar/halaszatitrvszoveteln.doc [03.01.2019]

9. Falusi Zs (2016) Betiltott halászat, megélhetés nélküli családok, Magyar Nemzet, 06 February 2016, https://mno.hu/hetvegimagazin/kotott-fogas-1327270 [09.01.2019]

10. Fazekas S (2016) Válasz Szabó Sándor országgyűlési képviselő "Kaphatnak-e kártalanítást a szegedi halászok?” írásban feltett kérdésére, Budapest, 21.01.2016, reference number: PTKF/83/2/2016

11. Kajner P., Fazekas I., Flachner Zs., Molnár G. \& Balogh P, Szelídvízország-Kézikönyv a Tisza menti ártéri gazdálkodás megalapozáááboz, elotiszaert.hu/ bovebben.php?id=1420 [07.01.2019]

12. Lenkovics B (2013) A tulajdonszerzés eredeti és származékos jellege, Polgári Jogi Kodifikáció (2), pp. 14-29.

13. Liptai N. (2015) A magyar halászat jelene és jövője, Koncz I \& Szova I, ed., PEME XI. PhD Konferencia Elóadásai, Professzorok az Európai Magyarországért Egyesület, Budapest, 2015, pp. 71-77.

14. Nagy K (2017) Hagyományos ártéri gazdálkodás: fenntarthatóság és az árvízvédelem megoldása, bttp://neuronhalo.bu/2017/03/26/hagyomanyos-arterigazdalkodas-fenntarthatosag-es-az-arvizvedelem-megoldasa [10.01.2019]

15. Olajos I. (2010) A halászati jog használatának speciális szabályai, in: Csák, Cs, ed., Agrárjog. A magyar agrárjog fejlódése az EU keretei köäött, Novotni Alapitvány, Miskolc, pp. 153-159.

16. Szzilágyi J E (2017) A halgazdálkodás jogi szabályozása, in: Csák Cs, Hornyák Zs, Kocsis B E, Olajos István, Kókai-Kunné Szabó Á \& Szilágyi J E, ed., Agrárjog A magyar agrár-és vidékefejlesztési jogi szabályozás lehetöségei a globalizálódó Európai Unióban, Miskolci Egyetemi Kiadó, Miskolc, pp. 161-167.

17. Veres Z (2001) Környezetjogi szempontok a tulajdonjog korlátozásához, De iurispudentiae et iure publico (4), pp. 1-55. 